\title{
Effects of hypercapnia on acid-base balance and osmo-/iono-regulation in prawns (Decapoda: Palaemonidae)
}

\author{
A. Dissanayake ${ }^{1, *}$, R. Clough ${ }^{2}$, J. I. Spicer ${ }^{3}$, M. B. Jones ${ }^{2}$ \\ ${ }^{1}$ Institute for East China Sea Research, Nagasaki University, Taira-machi 1551-7, Nagasaki 851-2213, Japan \\ ${ }^{2}$ Marine Institute, Portland Square, and ${ }^{3}$ Marine Biology and Ecology Research Centre, Davy Building, University of Plymouth, \\ Drake Circus, Plymouth PL4 8AA, UK
}

\begin{abstract}
Anthropogenic carbon dioxide-induced 'ocean acidification' is predicted to have major implications for marine organisms. As the oceans becomes increasingly hypercapnic (elevated $\mathrm{CO}_{2}$ ) and seawater $\mathrm{pH}$ decreases, the ability of organisms to maintain extracellular $\mathrm{pH}$ homeostasis (acidbase balance) may be compromised. Acid-base regulation occurs by ionic transport, where hydrogen and bicarbonate ions $\left(\mathrm{HCO}_{3}{ }^{-}\right)$are exchanged for sodium and chloride, respectively $\left(\mathrm{H}^{+} / \mathrm{Na}^{+}\right.$; $\left.\mathrm{HCO}_{3}{ }^{-} / \mathrm{Cl}^{-}\right)$, as exemplified by decapod crustaceans. Palaemonid prawns, in particular, are efficient hypo-ionic/osmotic regulators in seawater. We demonstrate that hypercapnic exposure $(0.3 \mathrm{kPa})$ results in short-term (5 to $14 \mathrm{~d}$ ) extracellular acidosis in 2 efficient ionic/osmo-regulators (thus, acid-base regulators), i.e. Palaemon elegans and $P$. serratus. Complete hypercapnic compensation was observed in both species after $30 \mathrm{~d}$ exposure with no effect on osmotic capacity, but at the expense of extracellular acid-base alteration (alkalosis). Furthermore, the predominantly subtidal species $P$. serratus was observed to be as tolerant as the intertidal species $P$. elegans, although 2 differing mechanisms of ionic regulation may be at work, with $P$. elegans and $P$. serratus displaying lower and elevated haemolymph ion concentrations (i.e. sodium, chloride and calcium), respectively.
\end{abstract}

KEY WORDS: Hypercapnia · 'Ocean acidification' · Acid-base balance · Osmotic and ionic regulation · Palaemon

Resale or republication not permitted without written consent of the publisher

\section{INTRODUCTION}

Since the beginning of the industrial revolution (ca. 1750), atmospheric levels of carbon dioxide $\left(\mathrm{CO}_{2}\right)$ have been steadily increasing. Present day levels of atmospheric $\mathrm{CO}_{2}$ (380 ppm) are greater than pre-industrial levels (280 ppm) (Feely et al. 2004). The increase in anthropogenic $\mathrm{CO}_{2}$, attributed to the burning of fossil fuels (IPCC 2001), has been rising at a far greater rate than previously recorded in the Earth's history (Pearson \& Palmer 2000). Under current models, continuously increasing production of $\mathrm{CO}_{2}$ emissions (under the 'business as-usual scenario') are predicted to raise the current atmospheric concentrations to $540 \mathrm{ppm}$ by the turn of the century, and ca. 2000 ppm by the year 2300 (Caldeira \& Wickett 2003). Oceans are regarded as natural 'sinks' for carbon and account for 30 to $50 \%$ of the atmospheric carbon that has been emitted over the last 250 yr (Siegenthaler \& Sarmiento 1993, Feely et al. 2004). As atmospheric carbon diffuses passively into the ocean surface waters, it alters seawater chemistry (Zeebe \& Wolf-Gladrow 2001). Carbonic acid $\left(\mathrm{H}_{2} \mathrm{CO}_{3}\right)$ is formed, which rapidly dissociates into bicarbonate ions $\left(\mathrm{HCO}_{3}{ }^{-}\right)$yielding hydrogen ions $\left(\mathrm{H}^{+}\right)$. This results in an increase in acidity (or decrease in $\mathrm{pH}$ ). The natural buffering of this reaction occurs by carbonate ions $\left(\mathrm{CO}_{3}{ }^{2-}\right)$ reacting with excess $\mathrm{H}^{+}$ions to form $\mathrm{HCO}_{3}{ }^{-}$, which is known as the carbonate buffering system, represented by the equation (Raven et al. 2005):

$\mathrm{CO}_{2}+\mathrm{H}_{2} \mathrm{O} \longleftrightarrow \mathrm{H}_{2} \mathrm{CO}_{3} \longleftrightarrow \mathrm{HCO}_{3}{ }^{-}+\mathrm{H}^{+} \longleftrightarrow \mathrm{CO}_{3}{ }^{2-}+2 \mathrm{H}^{+}$ 
The ocean's natural capacity to buffer changes in seawater chemistry caused by $\mathrm{CO}_{2}$ has been compromised and surface ocean $\mathrm{pH}$ has decreased by 0.1 units (since pre-industrial times) as a result of a $30 \%$ increase in $\mathrm{H}^{+}$ ions (Caldeira \& Wickett 2003, Blackford \& Gilbert 2007). The reduction in ocean $\mathrm{pH}$ is termed 'ocean acidification'. Responsible for this rapid rise in ocean acidity is increasing hypercapnia (elevated levels of dissolved $\mathrm{CO}_{2}$ ) (which drives the equilibria of Eq. 1 towards the right-hand side). This may have profound effects upon the biota, the critical limits and long-term effects of which are currently unknown (Pörtner et al. 1998, Seibel \& Walsh 2003, Widdicombe \& Spicer 2008).

It is likely that changes in seawater chemistry will affect the internal physiological functioning of marine organisms, such as the acid-base balance (Raven et al. 2005). Organisms that live in aquatic environments face the problem of maintaining a constant internal environment (i.e. acid-base balance in extracellular fluid) that enables cells to function efficiently and is independent of the external environment (Rankin \& Davenport 1981, Seibel \& Walsh 2003). Mechanisms of acid-base regulation require ion exchange with the external environment, where $\mathrm{H}^{+}$and $\mathrm{HCO}_{3}{ }^{-}$ions are used as counter-ions for sodium $\left(\mathrm{Na}^{+}\right)$and $\left(\mathrm{Cl}^{-}\right)$ $\left(\mathrm{HCO}_{3}{ }^{-} / \mathrm{Cl}^{-}\right.$and $\mathrm{H}^{+} / \mathrm{Na}^{+}$) (Cameron \& Mangum 1983, Mantel \& Farmer 1983, Wheatly \& Henry 1992). Ionic and osmotic regulation is defined as 'the maintenance in a body fluid of concentrations of ions (ionic) and total particle concentration (osmotic) differing to that the external medium' (Robertson 1949), and it is generally regarded that efficient ionic/osmotic regulators are efficient acid-base regulators. Examples of ionic/osmotic regulators include the decapod crustaceans (Robertson 1949). Some decapods, such as the Palaemonid prawns, have previously been shown to be efficient hyper- and hypo-ionic/osmoregulators in both low and high saline waters, respectively (Panikkar 1941, Parry 1954, Campbell \& Jones 1989, Freire et al. 2003, González-Ortegón et al. 2006), and are regarded as displaying an osmoregulatory ability which is the most advanced form of genetic adaptation to osmotic change (Kinne 1971). Palaemonid prawns occur throughout the world in a wide variety of aquatic habitats; the majority inhabit freshwater, while a few are marine species, and a minority are brackish-water species (Holthuis 1950).

Examples of palaemonids around coastal shallow UK waters include Palaemon elegans (Rathke), which is normally found in intertidal rock pools, and $P$. serratus (Pennant), which inhabits the subtidal or rock pools on the lower shore (Smaldon 1979). Both palaemonids can co-occur; however, $P$. serratus is restricted to the lower shore/subtidal areas due to abiotic factors (Berglund 1982). The physiology of $P$. elegans has been shown to more tolerant of the conditions associated with rock pools, such as daily and seasonal fluctuations in oxygen, pH, temperature (Truchot \& Duhamel-Jouve 1980, Morris \& Taylor 1983, Taylor \& Spicer 1991) compared with P. serratus (Taylor \& Spicer 1991).

The aim of the present study was to investigate the short-term effects of hypercapnia (due to $\mathrm{CO}_{2}$-acidified seawater exposure) on the relationship between osmotic and ionic regulation and acid-base balance in 2 palaemonids (Decapoda: Palaemonidae) that exhibit efficient hypo-osmo/ionoregulatory ability. One is primarily high shore in its distribution (Palaemon elegans) and the other is low shore/subtidal (P. serratus).

\section{MATERIALS AND METHODS}

Animal collection and maintenance. Palaemon elegans was collected from tidal pools using hand-held nets and $P$. serratus from LWS (low water spring) using baited creels at Mount Batten, Plymouth, UK $\left(50^{\circ} 21^{\prime} 26 \mathrm{~N}, 4^{\circ} 07^{\prime} 36 \mathrm{~W}\right)$ during November 2008. Only adults were used in the experiments described below. The body length (BL, rostrum to telson) of each was measured: $P$. elegans mean BL $41.48 \pm 3.0 \mathrm{~mm}$ and $P$. serratus mean BL $61.2 \pm 10.7 \mathrm{~mm}$. All prawns were maintained in a number of static holding aquaria (volume $=100 \mathrm{l})$ each containing filtered $(10 \mu \mathrm{m}$ carbon-filtered), continually aerated artificial seawater (ASW) (Instant Ocean ${ }^{\circledR}$, J\&K Aquatics; salinity of 32, $15 \pm 1^{\circ} \mathrm{C}, \mathrm{pH} 7.94 \pm 0.01$ ) under a $12 \mathrm{~h}$ light:12 h dark photoperiod.

Experimental design. Prawns were exposed to either control seawater (normocapnic: $0.1 \mathrm{kPa} \mathrm{CO}_{2}$ ) or hypercapnic seawater $(0.3 \mathrm{kPa} \mathrm{CO})$ for 5,14 or $30 \mathrm{~d}(\mathrm{n}=13$ for each exposure period). The $\mathrm{CO}_{2}$-enriched seawater for the experimental period was prepared as follows. 'Scrubbed air' (produced by bubbling through $2 \mathrm{~mol} \mathrm{l}^{-1}$ $\mathrm{NaOH}$ ) was mixed with $\mathrm{CO}_{2}$ to produce a nominal $\mathrm{CO}_{2}$ concentration. The resultant gas mixture was dried and, subsequently, measured using a $\mathrm{CO}_{2}$ analyser (Licor, LI-7000) and supplied to the seawater in the experimental tanks. The control (normocapnic) air was supplied to the seawater in the experimental tanks without any $\mathrm{CO}_{2}$ added. The gas volume added to each tank (irrespective of treatment) was $0.21 \mathrm{~min}^{-1}$. Details of seawater physico-chemical parameters for the $30 \mathrm{~d}$ exposure period are presented in Table 1. Prawns were held individually in aquaria (volume $=2 \mathrm{l}$ ) and fed artificial feed pellets $(0.07 \pm 0.001 \mathrm{~g})$ equivalent to $3 \%$ body mass for crustaceans (McGaw \& Reiber 2000, Dissanayake et al. 2008) (CrustaGran, Dennerle) every $2 \mathrm{~d}$. Water was changed within $18 \mathrm{~h}$ after feeding.

Haemolymph sampling. Acid-base studies using extracellular fluid (blood or haemolymph) have previ- 
Table 1. Palaemon elegans and P. serratus. Physico-chemical parameters (mean $\pm 1 \mathrm{SE}$ ) over the $30 \mathrm{~d}$ exposure period $(\mathrm{n}=13$ for each parameter). Water temperature $\left({ }^{\circ} \mathrm{C}\right)$ and salinity were $15 \pm 0.13$ and $32 \pm 0.1$, respectively

\begin{tabular}{|c|c|c|c|c|c|c|c|c|}
\hline $\begin{array}{l}\text { Treatment } \\
\text { Species }\end{array}$ & $\begin{array}{l}\text { Exposure } \\
\text { period } \\
\text { (d) }\end{array}$ & $\begin{array}{c}\text { Seawater } \\
\text { pH }\end{array}$ & $\begin{array}{c}\text { Seawater } \\
\mathrm{pCO}_{2} \\
(\mathrm{kPa})\end{array}$ & $\begin{array}{c}\text { Seawater total } \\
\text { alkalinity } \\
\left(\mu \mathrm{mol} \mathrm{kg}{ }^{-1}\right)\end{array}$ & $\begin{array}{c}\text { Calcite } \\
\text { saturation }\end{array}$ & $\begin{array}{l}\text { Aragonite } \\
\text { saturation }\end{array}$ & $\begin{array}{l}\text { Haemo- } \\
\text { lymph pCO } \\
(\mathrm{kPa})\end{array}$ & $\begin{array}{c}\text { Haemolymph } \\
{\left[\mathrm{HCO}_{3}^{-}\right]} \\
\left(\mathrm{mmol} \mathrm{l}^{-1}\right)\end{array}$ \\
\hline \multicolumn{9}{|c|}{ Control (0.1 kPa) } \\
\hline \multirow[t]{3}{*}{ P. elegans } & 5 & $7.98 \pm 0.01$ & $0.08 \pm 0.02$ & $2853 \pm 3.57$ & $3.12 \pm 0.05$ & $1.99 \pm 0.03$ & $0.29 \pm 0.01$ & $2.99 \pm 0.13$ \\
\hline & 14 & $7.96 \pm 0.01$ & $0.09 \pm 0.01$ & $3085 \pm 2.51$ & $3.28 \pm 0.04$ & $2.09 \pm 0.02$ & $0.22 \pm 0.01$ & $3.01 \pm 0.13$ \\
\hline & 30 & $7.95 \pm 0.01$ & $0.12 \pm 0.02$ & $3685 \pm 2.99$ & $3.79 \pm 0.05$ & $2.42 \pm 0.03$ & $0.44 \pm 0.01$ & $6.80 \pm 0.40$ \\
\hline \multirow[t]{3}{*}{ P. serratus } & 5 & $7.95 \pm 0.01$ & $0.11 \pm 0.02$ & $2829 \pm 26.87$ & $2.85 \pm 0.31$ & $1.82 \pm 0.20$ & $0.16 \pm 0.01$ & $2.14 \pm 0.20$ \\
\hline & 14 & $7.89 \pm 0.01$ & $0.11 \pm 0.02$ & $3283 \pm 1.76$ & $3.36 \pm 0.03$ & $2.15 \pm 0.02$ & $0.22 \pm 0.01$ & $2.92 \pm 0.01$ \\
\hline & 30 & $7.89 \pm 0.02$ & $0.14 \pm 0.05$ & $3657 \pm 7.98$ & $3.38 \pm 0.12$ & $2.16 \pm 0.07$ & $0.17 \pm 0.01$ & $3.23 \pm 0.10$ \\
\hline \multicolumn{9}{|c|}{ Hypercapnia (0.1kPa) } \\
\hline \multirow[t]{3}{*}{ P. elegans } & 5 & $7.40 \pm 0.02$ & $0.33 \pm 0.13$ & $2715 \pm 7.24$ & $0.86 \pm 0.04$ & $0.05 \pm 0.03$ & $0.25 \pm 0.01$ & $2.85 \pm 0.30$ \\
\hline & 14 & $7.51 \pm 0.01$ & $0.31 \pm 0.06$ & $3357 \pm 4.00$ & $1.36 \pm 0.03$ & $0.87 \pm 0.05$ & $0.28 \pm 0.01$ & $3.04 \pm 0.05$ \\
\hline & 30 & $7.49 \pm 0.01$ & $0.38 \pm 0.06$ & $3823 \pm 4.53$ & $1.47 \pm 0.03$ & $0.93 \pm 0.02$ & $0.66 \pm 0.01$ & $12.21 \pm 0.09$ \\
\hline \multirow[t]{3}{*}{ P. serratus } & 5 & $7.36 \pm 0.01$ & $0.36 \pm 0.10$ & $2699 \pm 5.25$ & $0.78 \pm 0.02$ & $0.50 \pm 0.01$ & $0.55 \pm 0.01$ & $6.99 \pm 0.49$ \\
\hline & 14 & $7.51 \pm 0.01$ & $0.32 \pm 0.10$ & $3363 \pm 6.38$ & $1.34 \pm 0.05$ & $0.86 \pm 0.03$ & $0.22 \pm 0.01$ & $3.58 \pm 0.01$ \\
\hline & 30 & $7.51 \pm 0.03$ & $0.37 \pm 0.10$ & $3855 \pm 14.76$ & $1.59 \pm 0.16$ & $1.02 \pm 0.10$ & $0.37 \pm 0.01$ & $7.66 \pm 0.24$ \\
\hline
\end{tabular}

ously been employed on catheterised individuals (e.g. fish, cuttlefish and large decapods) (Rahn \& Baumgardner 1972, Pane \& Barry 2007, Gutowska et al. 2010) to avoid problems associated with hyperventilation or hypoxia. In the present study, individual prawns could not be catheterised due to the small body size. Extracellular fluid was therefore collected as described by Taylor \& Spicer (1991). Individuals were collected from each tank containing exposure water (either 0.1 or $0.3 \mathrm{kPa}$ ) (no flight reactions were noted). Haemolymph was extracted using an ice-chilled Hamilton microsyringe (volume $=50 \mu \mathrm{l}$ ) on unanaesthetised individuals after thoroughly drying the cephalothorax using absorbent paper; the microsyringe needle was inserted directly into the pericardial cavity between the thorax and first abdominal segment (sampling time within $10 \mathrm{~s}$ ) (Campbell \& Jones 1989). The extracted haemolymph was then treated as follows.

Biological endpoints. All measurements were taken within $10 \mathrm{~s}$ of haemolymph sampling from each individual. Haemolymph osmolality was estimated for samples (volume $=8 \mu \mathrm{l}$ ) using a vapour pressure osmometer (Wescor 5500) (Campbell \& Jones 1989, Spicer et al. 2007). Results were expressed as osmotic capacity (or hypo-OC), defined as the difference between the osmolalities of haemolymph and the medium (ASW) (Charmantier \& Anger 1999, Lignot et al. 2000) as palaemonids hypo-osmoregulate in seawater (Panikkar 1941, Parry 1954). Total carbon dioxide content of haemolymph $\left(\mathrm{CCO}_{2} \mathrm{mmol} \mathrm{l}^{-1}\right)$ was measured using a $\mathrm{CO}_{2}$ analyser (Ciba-Corning 965) (Miles et al. 2007, Spicer et al. 2007). Haemolymph partial pressure of $\mathrm{CO}_{2}\left(\mathrm{pCO}_{2}\right)$ was then calculated from measured values for $\mathrm{CCO}_{2}$ and $\mathrm{pH}$ using a modified form of the Henderson-Hasselbalch equation, as employed by Miles et al.
(2007). Haemolymph (extracellular) pH and seawater $\mathrm{pH}$ was measured using a micro $\mathrm{pH}$ electrode equilibrated at $15^{\circ} \mathrm{C}$ (Mettler Toledo Inlab423) inserted directly into the sample in vitro within seconds of collection. Using the $\mathrm{pH}$ and $\mathrm{CCO}_{2}$ data, values for bicarbonate concentration $\left[\mathrm{HCO}_{3}{ }^{-}\right]$and the saturation states for calcium and aragonite were calculated for each time point $(5,14$ and $30 \mathrm{~d})$ using the CO2SYS program (Pierrot et al. 2006) and are presented in Table 1.

Haemolymph ion concentrations. Haemolymph concentrations of ions (sodium $\mathrm{Na}^{+}$, calcium $\mathrm{Ca}^{2+}$, potassium $\mathrm{K}^{+}$and magnesium $\mathrm{Mg}^{2+}$ ) were measured, after appropriate dilution with double de-ionised water, using an inductively-coupled plasma optical emission spectrophotometer (ICP-OES, Varian 725 ES). An independent check standard, prepared from different stock solutions to those used for the calibration standards, was used to confirm instrumental performance throughout the analytical procedure. The analysis was conducted under ISO 9001:2000 certification. Chloride concentrations were determined spectrophotometrically at $480 \mathrm{~nm}$ using a microtitre plate format with ferric nitrate and mercuric thiocyanate, and using sodium chloride as a standard solution (Merchant 2009).

Statistical analysis. Analysis of variance (ANOVA) tests were performed to test for differences (as revealed by Student-Newman-Keuls, SNK, tests) in (1) exposure level (normocapnia control or hypercapnia) or (2) time $\left(5,14\right.$, or 30 d) using GMAV for Windows ${ }^{\circledR}$ (Underwood 2005). Prior to analysis, data was tested for normality using Cochran's test and transformed where necessary (square-root or log-transformed where the data range was either within the same order of magnitude or within different orders of magnitude, respectively) (see 'Results'). 


\section{RESULTS}

\section{Haemolymph pH and osmotic capacity (hypo-OC)}

Changes were observed in the osmotic capability of Palaemon elegans only after $14 \mathrm{~d}$ ( $5 \mathrm{~d}: F_{1,24}=0.08, \mathrm{p}=$ $0.78 ; 14 \mathrm{~d}: F_{1,24}=15.85, \mathrm{p}=<0.001 ; 30 \mathrm{~d}: F_{1,24}=0.38, \mathrm{p}=$ 0.38) (Fig. 1) and $5 \mathrm{~d}$ in P. serratus (5 d: $F_{1,24}=150.18$, $\mathrm{p}=<0.001 ; 14 \mathrm{~d}: F_{1,24}=2.67, \mathrm{p}=0.12 ; 30 \mathrm{~d}: F_{1,24}=1.03$, $\mathrm{p}=0.32$ ), with hypo-osmotic capacity reaching similar levels to that of normocapnic individuals after $30 \mathrm{~d}$ in both species. With respect to haemolymph $\mathrm{pH}$, a significant decrease was observed in hypercapnia-exposed individuals of both species compared to respective con-

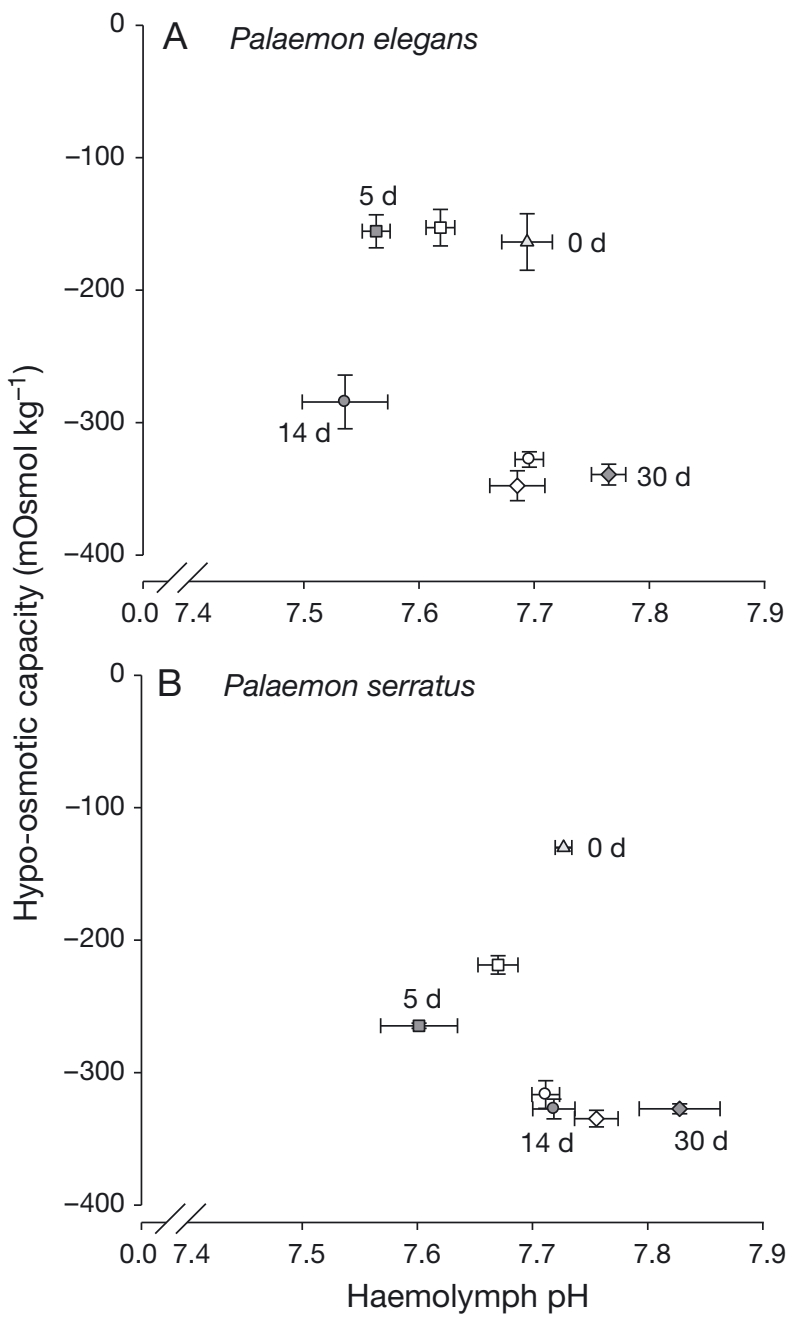

Fig. 1. Palaemon elegans and $P$. serratus. Relationship between osmotic capacity and haemolymph $\mathrm{pH}$ (mean $\pm \mathrm{SE}$ ) in (A) P. elegans and (B) P. serratus showing time course (in d) of haemolymph acid-base alterations over a $30 \mathrm{~d}$ hypercapnic exposure $(0.3 \mathrm{kPa})$. Open symbols and filled symbols indicate control (normocapnic) and hypercapnic treatments, respectively. $(\Delta) 0 \mathrm{~d}$ (control value), $(\square, 0, \diamond) 5,14$ and $30 \mathrm{~d}$, respectively, and time course of values from hypercapnia-exposed individuals are labelled $(\mathrm{n}=13)$ trols (after 5 d). Following 14 d hypercapnia exposure, haemolymph $\mathrm{pH}$ values returned to pre-exposure levels in P. serratus; however, in P. elegans, hypercapnia resulted in further sustained haemolymph acidosis. After $30 \mathrm{~d}$ hypercapnia exposure, however, there was a significant haemolymph alkalosis, compared with control individuals, in both species (control vs. hypercapnia exposure: $P$. elegans: $F_{2,72}=31.77, \mathrm{p}=<0.001$; P. serratus: $\left.F_{2,72}=5.2, \mathrm{p}<0.01\right)$.

Hypercapnia-exposed Palaemon serratus individuals experienced greater variation in internal $\mathrm{pH}(\Delta \mathrm{pH})$ (on average) compared with hypercapnic $P$. elegans individuals $(\Delta \mathrm{pH}=0.23$ compared to $\Delta \mathrm{pH}=0.2$ in $P$. serratus and $P$. elegans, respectively). There was no difference in haemolymph $\mathrm{pH}$ between controls from the start to the end of the exposure $(0$ and $30 \mathrm{~d})\left(P\right.$. elegans: $F_{1,24}=0.07$, $\mathrm{p}=0.80 ; P$. serratus: $\left.F_{1,24}=0.07, \mathrm{p}=0.44\right)$. Thirty d hypercapnic exposure resulted in a new 'steady state' in osmotic capacity, similar to that of normocapnic (control) individuals; however, at the expense of significant acid-base balance shift to haemolymph alkalosis.

\section{Haemolymph ion concentrations}

Sodium. With regard to sodium ion concentration in Palaemon elegans, the only significant differences were observed after $14 \mathrm{~d}$, with hypercapnic individuals displaying lower sodium concentrations compared to normocapnic individuals $\left(F_{2,72}=11.37, \mathrm{p}<0.001\right)$ (Fig. 2A). Conversely, in $P$. serratus, hypercapniaexposed individuals had greater haemolymph sodium ion concentrations after 5 and 14 d exposure (hypercapnia vs. normocapnia: square root-transformed: $F_{1,72}=15.99, \mathrm{p}<0.001$; time: square root-transformed: $F_{2,72}=10.84, \mathrm{p}<0.001$ ) (Fig. 2B).

Chloride. Chloride regulation in Palaemon elegans matched the pattern of sodium regulation with significantly lower chloride concentrations in hypercapnic individuals compared with control individuals after $14 \mathrm{~d}$ $\left(F_{2,72}=5.60, \mathrm{p}<0.01\right)$ (Fig. 3A). In P. serratus, conversely, a different pattern was observed, with significantly higher haemolymph concentrations observed after $14 \mathrm{~d}$ (log-transformed: $F_{2,72}=9.13, \mathrm{p}<0.001$ ) (Fig. 3B).

Calcium. No difference in calcium concentrations were observed after 5 d exposure in Palaemon elegans (Fig. 4A). After 14 d, hypercapnic P. elegans individuals displayed significantly lower calcium concentrations compared with controls, matching the pattern seen with sodium and chloride; however, there were no differences in calcium concentrations between control and hypercapnia-exposed individuals after $30 \mathrm{~d}\left(F_{2,72}=\right.$ 8.81, p < 0.001). Conversely, with $P$. serratus, hyperregulation of internal calcium was observed in hypercapnic individuals after both 5 and $14 \mathrm{~d}$ exposure. After 


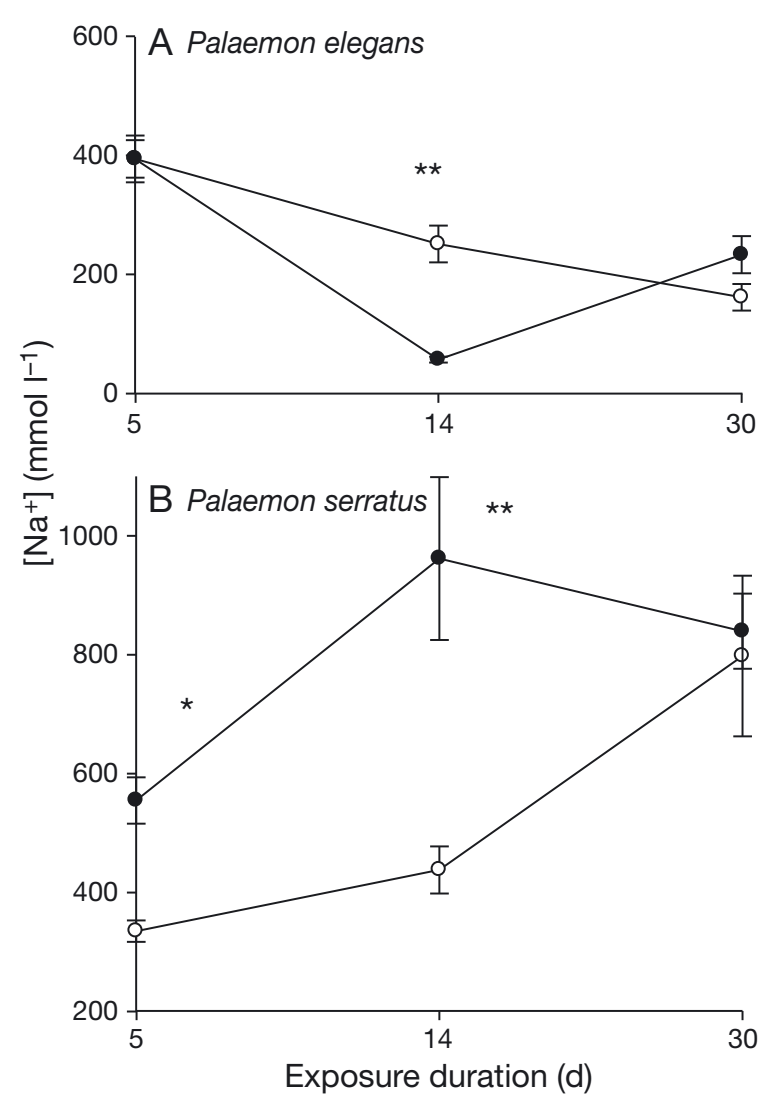

Fig. 2. Palaemon elegans and P. serratus. Haemolymph sodium concentrations (mean $\pm \mathrm{SE})\left(\mathrm{mmol} \mathrm{l}^{-1}\right)$ in (A) P. elegans and (B) P. serratus. $\bigcirc$ and $\bullet$ indicate control (normocapnic) and hypercapnic treatments, respectively. ${ }^{*} \mathrm{p}<0.05,{ }^{* *} \mathrm{p}<$ $0.001(\mathrm{n}=13)$

$30 \mathrm{~d}$, there were no significant differences between normocapnic and hypercapnic individuals (square roottransformed: $F_{2,72}=3.45, \mathrm{p}<0.05$ ) (Fig. 4B).

Potassium. The only significant differences in internal potassium concentrations in Palaemon elegans were after $5 \mathrm{~d}$ (log-transformed: $F_{1,72}=4.51, \mathrm{p}<0.05$ ) (Fig. 5A). With regard to $P$. serratus, however, there were no significant differences between hypercapnic and normocapnic individuals (Fig. 5B).

Magnesium. There were differences in haemolymph magnesium concentrations, with hypercapnic individuals of both species displaying significantly lower magnesium concentrations compared with control individuals after 5 and $14 \mathrm{~d}$ (only in Palaemon elegans) $(P$. elegans: log-transformed: $F_{1,72}=2.50, \mathrm{p}<0.001$; $P$. serratus: log-transformed: $F_{2,72}=6.08, \mathrm{p}<0.001$ ) (Fig. 6A,B).

\section{Haemolymph ion ratios}

Palaemon serratus exhibits a rapid compensation for hypercapnic acidosis as shown by a 2 - and 4.7 -fold change increase in bicarbonate:calcium and bicarbon-

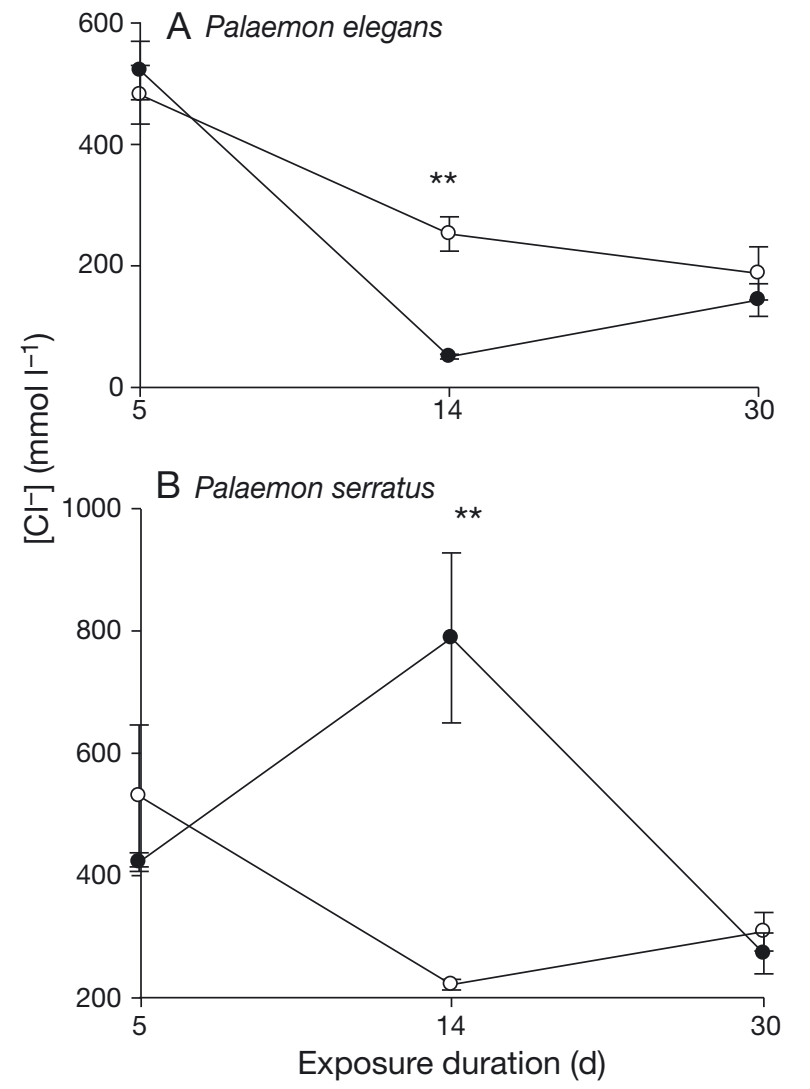

Fig. 3. Palaemon elegans and P. serratus. Haemolymph chloride concentrations (mean $\pm \mathrm{SE})\left(\mathrm{mmol} \mathrm{l}^{-1}\right)$ in $(\mathrm{A})$ P. elegans and (B) P. serratus. $O$ and $\bullet$ indicate control (normocapnic) and hypercapnic treatments, respectively. ${ }^{*} \mathrm{p}<0.05,{ }^{* *} \mathrm{p}<$ $0.001(\mathrm{n}=13)$

ate:chloride exchanges at $5 \mathrm{~d}$ compared to $P$. elegans (Table 2). However, after $14 \mathrm{~d}$, an increase in bicarbonate buffering occurs in P. elegans as indicated by a 4and 5-fold increase in bicarbonate exchange compared to calcium and chloride ions, respectively (Table 2). Differing mechanisms of ion regulation are expected to occur between the 2 species as indicated by the lower ion concentrations in P. elegans and the increasing ion concentrations in P. serratus over time (Figs. 2-6) and compared to the respective controls and in situ values (Parry 1954, Ramirez de Isla Hernandez \& Taylor 1985) (Table 3).

\section{DISCUSSION}

Haemolymph acidosis was observed in both species after $5 \mathrm{~d}$, coupled with an increase in hypo-osmotic capacity after $5 \mathrm{~d}$ in Palaemon serratus and after $14 \mathrm{~d}$ in P. elegans. After $14 \mathrm{~d}$, extracellular $\mathrm{pH}$ in P. elegans was still depressed but was not significantly different from the control in P. serratus. Hypercapnia-related changes to extracellular $\mathrm{pH}$ may be linked to altered 


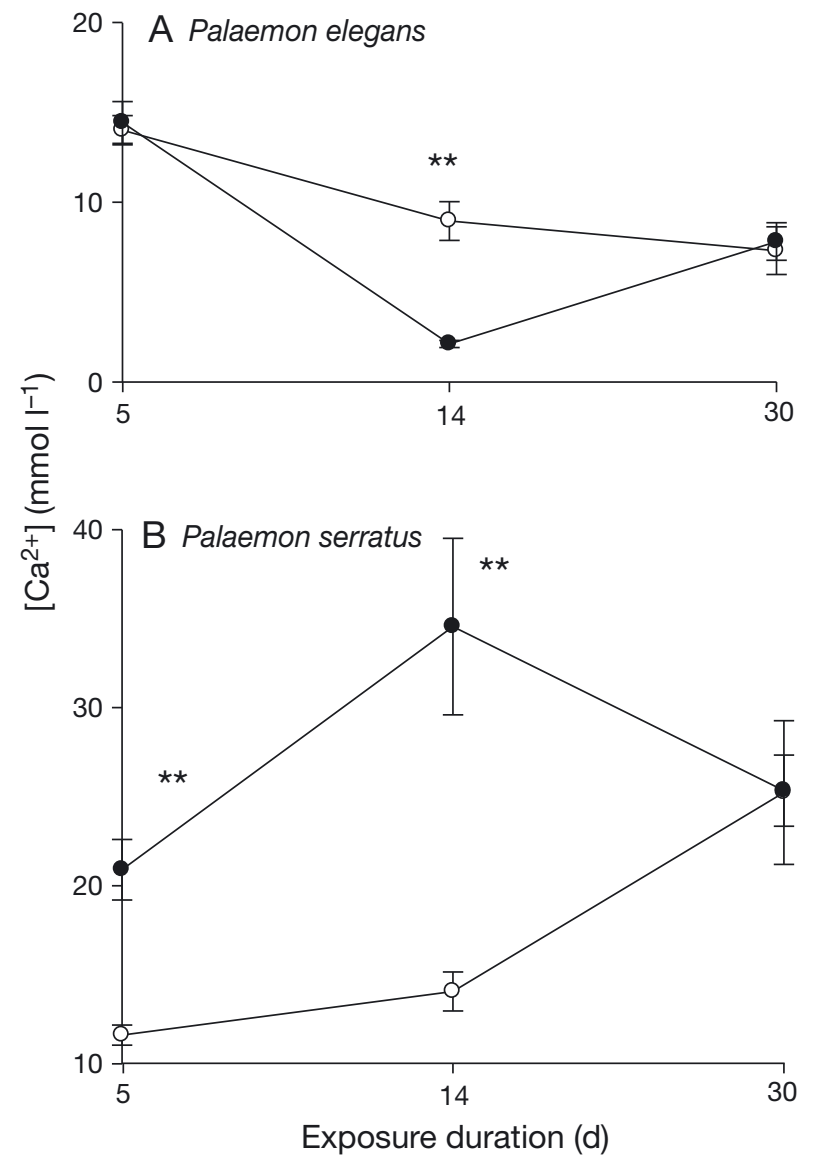

Fig. 4. Palaemon elegans and P. serratus. Haemolymph calcium concentrations (mean $\pm \mathrm{SE})\left(\mathrm{mmol} \mathrm{l}^{-1}\right)$ in (A) P. elegans and (B) P. serratus. $O$ and $\bullet$ indicate control (normocapnic) and hypercapnic treatments, respectively. ${ }^{*} \mathrm{p}<0.05,{ }^{* *} \mathrm{p}<$ $0.001(\mathrm{n}=13)$

ionic regulation, as indicated by decreased (P. elegans) and elevated (P. serratus) ion concentrations in haemolymph, thereby acting as a compensatory mechanism of ion exchange to buffer changes in internal $\mathrm{pH}$. Although the exact mechanism is as yet unclear, ion regulatory changes may result from an up-regulation of $\mathrm{Na}^{+} / \mathrm{K}^{+}$-ATPase, the enzyme responsible for ion exchange, as shown previously for palaemonids and other decapods (Freire et al. 2007, Mendonça et al. 2007, Ituarte et al. 2008, Masui et al. 2009). Palaemonids actively pump out sodium and chloride ions (in seawater) in order to regulate the ionic composition of haemolymph in seawater $\left(P\right.$. serratus $459 \mathrm{mmol} \mathrm{l}^{-1}$ at $15^{\circ} \mathrm{C}_{i}$ P. elegans 320 and $398 \mathrm{mmol} \mathrm{l}^{-1}$ at 10 and $20^{\circ} \mathrm{C}$, respectively) (Parry 1954, Ramirez de Isla Hernandez \& Taylor 1985), thereby maintaining the internal medium hypo-osmotic to that of the external medium (seawater) (Table 3).

Hypercapnia exposure due to increased $\mathrm{CO}_{2}$ concentration, as shown here, resulted in species-specific responses in 2 efficient osmotic/ionic regulators. There
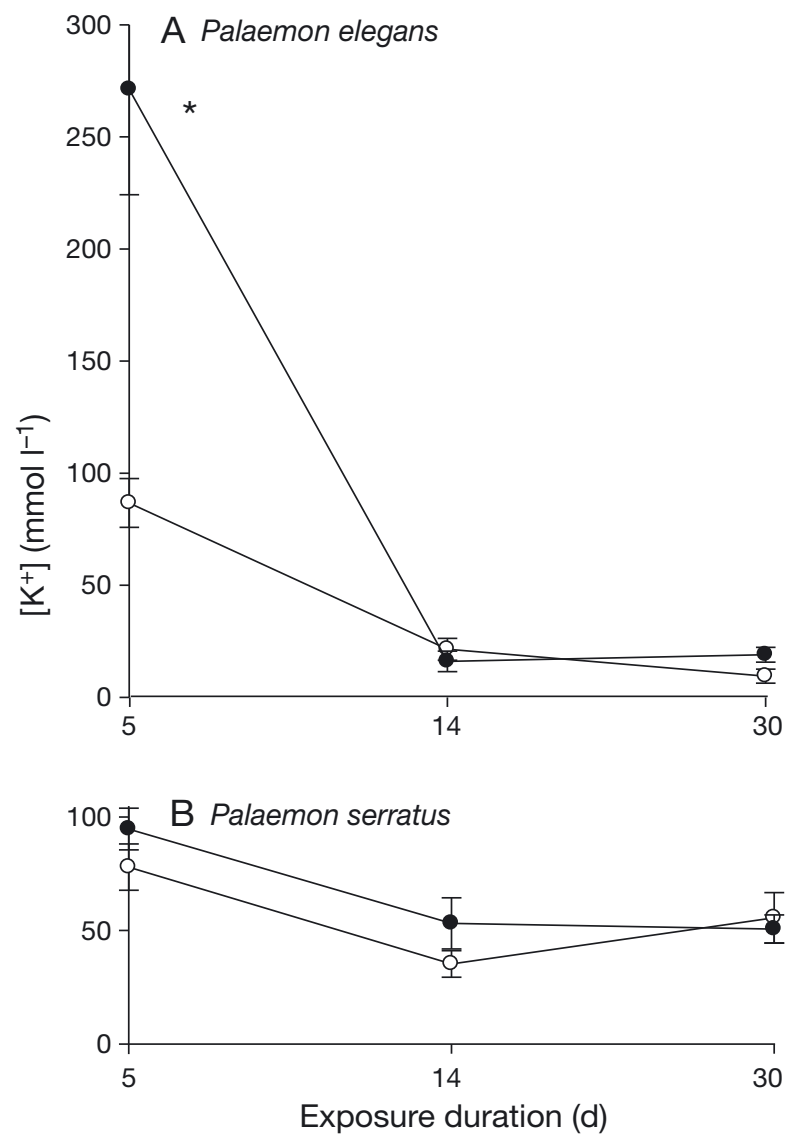

Fig. 5. Palaemon elegans and P. serratus. Haemolymph potassium concentrations (mean $\pm \mathrm{SE})\left(\mathrm{mmol} \mathrm{l}^{-1}\right)$ in (A) P. elegans and (B) P. serratus. $\bigcirc$ and $\bullet$ indicate control (normocapnic) and hypercapnic treatments, respectively. ${ }^{*} \mathrm{p}<0.05,{ }^{* *} \mathrm{p}<$ $0.001(\mathrm{n}=13)$

was a general pattern of increased haemolymph ionic concentrations (particularly $\mathrm{Na}^{+}, \mathrm{Cl}^{-}$and $\mathrm{Ca}^{2+}$ ) in Palaemon serratus, and decreased ionic concentrations in $P$. elegans compared to respective controls. Specifically regarding $\mathrm{Ca}^{2+}$, an increase in haemolymph $\left[\mathrm{Ca}^{2+}\right]$ could arise from exoskeleton dissolution. In decapod crustaceans, dissolution of the exoskeleton yields bicarbonate (and thus calcium), which may be used for buffering of acid-base alterations. This has been observed in the blue crab under hypercapnic conditions, although the carapace played a minor role in hypercapnic buffering, whereas branchial ionic exchanges (at the gills) accounted for most of the compensatory exchanges (Cameron 1985). Spicer et al. (2007) demonstrated a $20 \%$ decrease in osmolality in hypercapnia-exposed individuals of the decapod crustacean species Necora puber, with a associated rise in $\mathrm{Ca}^{2+}$ and $\mathrm{Mg}^{2+}$ ions in haemolymph (2 to $6 \mathrm{~d}$ ). Although these authors could not ascertain the exact mechanism of elevated $\mathrm{Ca}^{2+}$ and $\mathrm{Mg}^{2+}$ ions in their study, they claim bicarbonate buffering could be 'sourced' from 


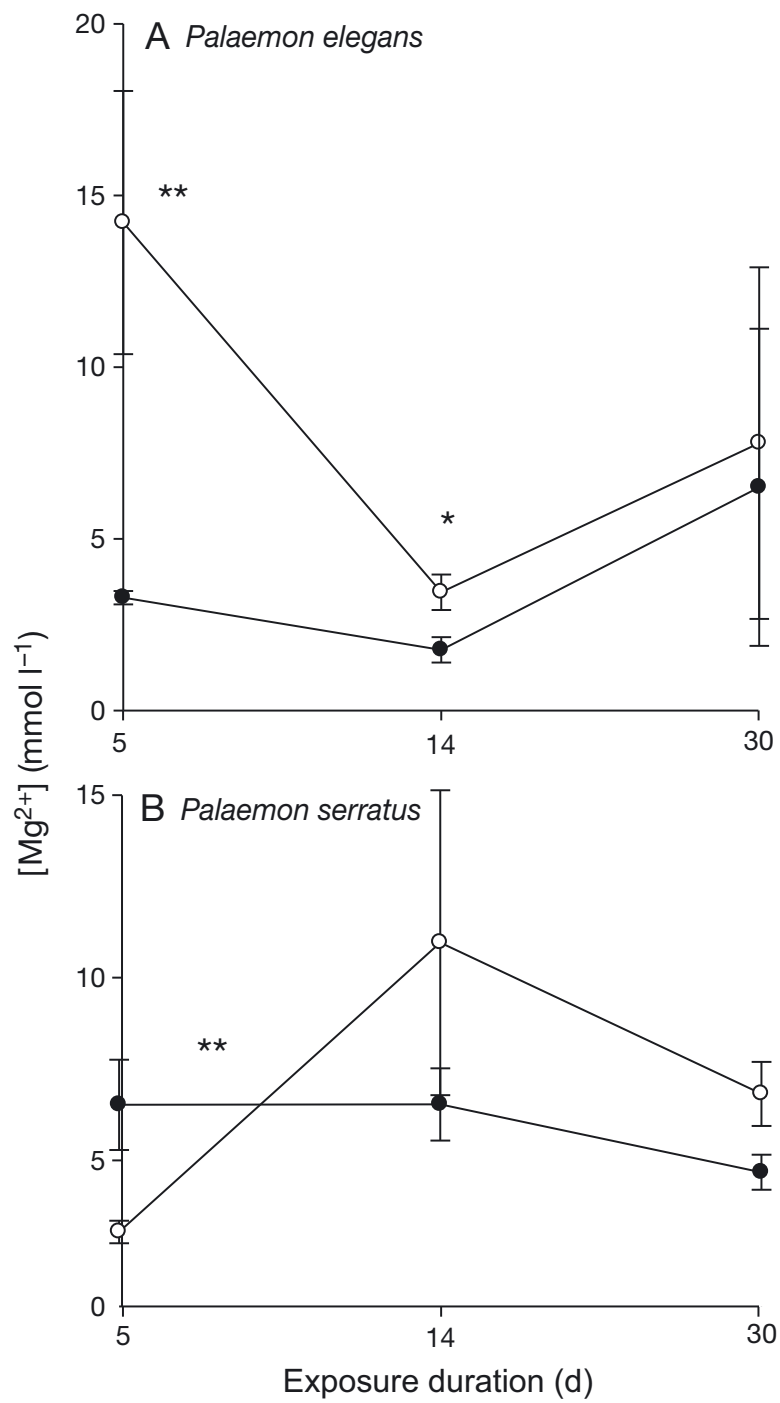

Fig. 6. Palaemon elegans and P. serratus. Haemolymph magnesium concentrations (mean $\pm \mathrm{SE})\left(\mathrm{mmol} \mathrm{l}^{-1}\right)$ in (A) P. elegans and (B) P. serratus. $\bigcirc$ and $\bullet$ indicate control (normocapnic) and hypercapnic treatments, respectively. ${ }^{*} \mathrm{p}<0.05$, ${ }^{* *} \mathrm{p}<0.001(\mathrm{n}=13)$

the seawater rather than the exoskeleton. In our study, we also could not identify the exact mechanism or origin of elevated divalent ions. The comparative ratio between $\left[\mathrm{HCO}_{3}{ }^{-}\right]$and $\Delta \mathrm{Ca}^{2+}$ (as calculated by Henry et al. 1981) for both palaemonid species could elucidate the magnitude of the ion transport mechanism (Table 2). The compensation in hypercapnic acidosis with concomitant change in hypo-osmotic capacity may be linked to exchanges of bicarbonate, calcium and chloride. $P$. serratus exhibited a faster compensation for hypercapnic acidosis as shown by a 2- and 4.7fold increase in bicarbonate:calcium and bicarbonate: chloride exchanges at $5 \mathrm{~d}$ compared to $P$. elegans, and also by the lower ion concentrations in $P$. elegans and the increased ion concentrations in $P$. serratus over time compared to respective controls (Figs. 2-6, Table 3). Carbonic anhydrase plays a role in supplying counter-ions $\left(\mathrm{H}^{+}\right.$and $\left.\mathrm{HCO}_{3}{ }^{-}\right)$for ionic exchange through the hydration of respired $\mathrm{CO}_{2}$ and plays an important role in $\mathrm{CO}_{2}$ excretion and acid-base balance (Henry \& Cameron 1983, McMahon et al. 1984). It could be hypothesised that under hypercapnia exposure any upregulation in carbonic anhydrase (and also $\mathrm{Na}^{+} / \mathrm{K}^{+}$ATPase, as mentioned previously) could serve to compensate for hypercapnic changes in acid-base balance as a result of active ion transport (Henry \& Wheatly 1992, Seibel \& Walsh 2003), although $90 \%$ of bicarbonate sourced is 'sourced' from seawater (Cameron 1985).

The major physiological changes in 2 closely related species which inhabit different environments (rock pools and subtidal areas) could provide fundamental insights into the adaptive responses and small scale phenotypic evolution in decapod crustacean species. The differential pattern of haemolymph ions $\left(\mathrm{Na}^{+}, \mathrm{Cl}^{-}\right.$ and $\mathrm{Ca}^{2+}$ ) observed here and, particularly, decreased $\left[\mathrm{Ca}^{2+}\right]$ in Palaemon elegans and elevated $\left[\mathrm{Ca}^{2+}\right]$ in $P$. serratus could signal species-specific differences in the mechanisms used to compensate for hypercapnic conditions. The gills of Palaemonid prawns are the most vital organs in osmoregulation (sodium and chloride ions), as the renal organs play an unimportant role (Panikkar 1941, Parry 1954, Freire et al. 2003). In seawater, palaemonids compensate for passive salt influx by active salt excretion and active water uptake, thereby achieving hypo-osmotic regulation in seawater, although the exact mechanism is unknown (Freire et al. 2008). The increased hypo-osmotic capability (i.e. lowering of osmolality), as seen here, may thus arise by either a combination of active secretion of ions and/or active transport of water against the osmotic gradient, as indicated by a lower ion concentration in $P$. elegans (Panikkar 1941), which would account for the observed differential pattern of ion regulation. Augusto et al. (2009) observed a decrease in haemolymph osmolality and a concomitant increase in both sodium and chloride haemolymph ion concentrations linked to an increase in muscle tissue water content in the intertidal $P$. northropi when acutely exposed to lower salinities. The elevated ionic concentrations $\left(\mathrm{Na}^{+}, \mathrm{Cl}^{-}\right.$and $\left.\mathrm{Ca}^{2+}\right)$ and lowered osmolality (as observed here) may occur via similar mechanisms when palaemonids are exposed to lower salinities (Augusto et al. 2009), as P. serratus also retains this capability. Long-term hypercapnia exposure (30 d) had no effect on osmotic capacity, as values were similar to those of control individuals, suggesting acclimatory effects, since osmolality values are lower than those obtained in situ (0 d) and from previous studies (calculated from Panikkar 1941, Janas \& Spicer 2008). 
Table 2. Palaemon elegans and $P$. serratus. Average changes in ion concentration ( $\mathrm{mmol} \mathrm{l}^{-1}$ ) with hypercapnia exposure over time. Ratio values ca. 1 indicate equivalent changes in ion, $>1$ represent greater loss in primary exchange ion and $<1$ represent greater increase in secondary exchange ion

\begin{tabular}{|ccccccc|}
\hline Species & Time (d) & $\Delta \mathrm{HCO}_{3}{ }^{-}$ & $\Delta \mathrm{Ca}^{2+}$ & $\Delta \mathrm{Cl}^{-}$ & $\mathrm{HCO}_{3}: \mathrm{Ca}^{2+}$ & $\mathrm{HCO}_{3}{ }^{-}: \mathrm{Cl}^{-}$ \\
\hline Palaemon & 5 & 0.95 & 1.03 & 1.08 & 0.93 & 0.88 \\
elegans & 14 & 1.01 & 0.24 & 0.20 & 4.28 & 5.06 \\
& 30 & 1.80 & 1.07 & 0.67 & 1.68 & 2.69 \\
Palaemon & 5 & 3.27 & 1.80 & 0.80 & 1.81 & 4.10 \\
serratus & 14 & 1.23 & 2.37 & 3.57 & 0.52 & 0.34 \\
& 30 & 2.35 & 1.00 & 0.88 & 2.36 & 2.66 \\
\hline
\end{tabular}

Table 3. Palaemon elegans and P. serratus. Ionic composition of seawater $\left(\mathrm{mmol} \mathrm{l} \mathrm{l}^{-1}\right)$ and extracellular fluid (expressed as percentage of seawater) for $P$. elegans and $P$. serratus

\begin{tabular}{|c|c|c|c|c|c|c|}
\hline Ions & & $\mathrm{Na}^{+}$ & $\mathrm{Cl}^{-}$ & $\mathrm{Ca}^{2+}$ & $\mathrm{K}^{+}$ & $\mathrm{Mg}^{2+}$ \\
\hline Seawater $\left(\mathrm{mmol}^{-1}\right)^{\mathrm{a}}$ & & 418 & 541 & 17 & 9 & 76 \\
\hline Palaemon elegans ${ }^{\mathrm{a}}$ & $\begin{array}{l}10^{\circ} \mathrm{C} \\
20^{\circ} \mathrm{C}\end{array}$ & $\begin{array}{l}77 \\
95\end{array}$ & $\begin{array}{l}57 \\
83\end{array}$ & $\begin{array}{l}206 \\
165\end{array}$ & $\begin{array}{l}83 \\
86\end{array}$ & $\begin{array}{l}5 \\
9\end{array}$ \\
\hline 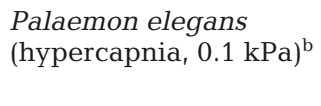 & $\begin{array}{r}5 \mathrm{~d} \\
14 \mathrm{~d} \\
30 \mathrm{~d}\end{array}$ & $\begin{array}{l}94 \\
14 \\
49\end{array}$ & $\begin{array}{r}102 \\
9 \\
23\end{array}$ & $\begin{array}{l}82 \\
12 \\
47\end{array}$ & $\begin{array}{l}301 \\
178 \\
211\end{array}$ & $\begin{array}{r}4 \\
3 \\
13\end{array}$ \\
\hline Palaemon serratus ${ }^{\mathrm{C}}$ & $15^{\circ} \mathrm{C}$ & 85 & 85 & 106 & 85 & 20 \\
\hline $\begin{array}{l}\text { Palaemon serratus } \\
\left(^{(h y p e r c a p n i a, ~} 0.1 \mathrm{kPa}\right)^{\mathrm{b}}\end{array}$ & $\begin{array}{r}5 \mathrm{~d} \\
14 \mathrm{~d} \\
30 \mathrm{~d}\end{array}$ & $\begin{array}{l}133 \\
230 \\
201\end{array}$ & $\begin{array}{r}78 \\
146 \\
50\end{array}$ & $\begin{array}{l}124 \\
206 \\
147\end{array}$ & $\begin{array}{r}1056 \\
589 \\
556\end{array}$ & $\begin{array}{l}9 \\
9 \\
7\end{array}$ \\
\hline
\end{tabular}

Haemolymph acid-base disturbances in aquatic decapod crustaceans have been well-documented, with regard to temperature (Whiteley et al. 1995), salinity (Whiteley et al. 2001) and hypercapnia (Cameron 1985, Cameron \& Iwama 1987). Short-term hypoxia and hypercapnia exposure $\left(\mathrm{pO}_{2}=10\right.$ torr, $1.33 \mathrm{kPa}$; $\mathrm{pCO} 2=$ 0.74 torr, $0.10 \mathrm{kPa}$ for 3 to $6 \mathrm{~h}$ ) has previously been shown to cause significant deviations in acid-base disturbance in both Palaemon elegans and P. serratus (Taylor \& Spicer 1991). Significant alterations in blood parameters were found in $P$. serratus, with haemolymph alkalosis after 3 to $6 \mathrm{~h}$ and significant acidosis observed after a further $3 \mathrm{~h}$, even after return to normoxic conditions. In $P$. elegans, however, haemolymph alkalosis was negated by a return to normal levels when transferred to normoxic conditions. A significant increase in haemolymph L-lactate concentrations was observed in both species after hypoxia exposure and was assumed to be a result of anaerobic metabolism (Taylor \& Spicer 1987). The marked recovery observed in $P$. elegans is perhaps due to the species-specific ability to metabolise L-lactate accumulated under hypoxic conditions, in contrast to $P$. serratus. In the present study, a significant haemolymph acidosis was also observed in both species, which could have arisen as a result of both decreased external $\mathrm{pH}$ (exogenous) and, to some extent, accumulation of $\mathrm{H}^{+}$ions via L-lactate production as a result of anaerobic metabolism (endogenous). Unfortunately, we did not measure lactate production in the present study. A similar pattern of haemolymph acidosis with short-term hypercapnia exposure ( 5 to $14 \mathrm{~d}$ ) has been previously reported in 5 decapod crustaceans: Callinectes sapidus ( $2 \% \mathrm{CO}_{2}$ ca. 15000 ppm) (Cameron 1985, Cameron \& Iwama 1987), Cancer magister and Chionectes tanneri $\left(1 \% \mathrm{CO}_{2}\right.$ ca. 12800 ppm) (Pane \& Barry 2007), Carcinus maenas (0.3 kPa $\mathrm{pCO}_{2}$ ) (Truchot 1975) and Necora puber (6 kPa $\mathrm{pCO}_{2}$ ) (Spicer et al. 2007). Compensation for respiratory acidosis was observed in these species and could be explained by the degree of osmo/ionic regulatory ability of these organisms (with the exception of the deep sea crab Chionectes tanneri, which is a weak acid-base regulator; Pane \& Barry 2007). Those organisms that are weak osmo/ionic regulators or even osmoconformers, such as sea urchins, could possibly be more susceptible to external $\mathrm{pH}$ changes, as shown for the echinoid Psammechinus miliaris. Miles et al. (2007) observed sustained haemolymph acidosis and incomplete compensation over an $8 \mathrm{~d}$ period in urchins exposed to decreased seawater $\mathrm{pH}$ levels ( 7.44 to 6.14 ). This pattern of uncompensated acidosis has also been observed in sea urchins exposed to emersion from water and environmental hypoxia (Spicer 1995, Burnett et al. 2002), which indicates that only efficient osmotic/ionic regulators have the capacity to compensate acid-base disturbances. The control treatment in the present study was ca. $0.1 \mathrm{kPa}$ (i.e. $1000 \mu \mathrm{atm} \mathrm{CO}_{2}$ ), and excess (i.e. above ambient $0.04 \mathrm{kPa}$ ) probably resulted from bacterial proton production of nitrifying bacteria in biofiltration systems (which is commonly found in recirculating experimental systems). As such, these protons titrate total alkalinity down and cause high $\mathrm{pCO}_{2}$ despite equilibration with ambient air. Partial pressures of $\mathrm{CO}_{2}$ of $0.1 \mathrm{kPa}$ (as used here) are similar to 'normal' conditions ( 0.03 to $0.19 \mathrm{kPa})$ that exist in rock pools and subtidal areas (due dense algal growth) where these 2 Palaemonid species are found (Morris \& Taylor 1983, Taylor \& Spicer 1991)

Present results indicate that both Palaemon elegans and $P$. serratus are tolerant of hypercapnic exposure and, in addition, compensation for acidosis results in long-term haemolymph alkalosis and may disrupt ionic regulation, although haemolymph osmolality was 
similar to control values. While $P$. elegans may be subjected to the rapid changes in $\mathrm{pCO}_{2}$ associated with intertidal rock pools (e.g. changes in abiotic factors, such as $\mathrm{pH}$ and $\mathrm{CO}_{2}$ ), $P$. serratus is also tolerant of hypercapnia exposure, although 2 differing mechanisms of ionic regulation may be at work. In summary, hypercapnia exposure due to elevated environmental $\mathrm{CO}_{2}$ levels by 'ocean acidification' causes a short-term hypercapnic acidosis in 2 efficient osmotic/ionic regulatory species, but compensatory effects result in significant 'off-shoot' in acid-base balance (i.e. alkalosis). Furthermore, species-specific mechanistic differences in ion regulatory ability were revealed, with the predominantly subtidal species $P$. serratus displaying elevated ionic concentrations, in particular, elevated haemolymph sodium, chloride and calcium. Present results suggests that in the short-term (in terms of days), invertebrates that possess ionic regulatory ability experience acid-base imbalances, but have the capacity to compensate for such effects. However, questions remain about the long-term effects: Can these compensatory effects be sustained (i.e. active ion transport) and at what cost to the individual? An inability to control acid-base imbalances in the extracellular fluid may lead directly to further physiological costs, e.g. metabolic suppression, reduced scope for activity and, ultimately, death (Seibel \& Walsh 2003). Kurihara et al. (2008) reported significant physiological effects in the Palaemonid P. pacificus when exposed to longterm hypercapnic conditions (1900 ppmv $\mathrm{CO}_{2}$ for $49 \mathrm{~d}$ ). Growth was significantly depressed in hypercapnic individuals, leading to significant mortality, compared to control individuals. The long-term effects of 'ocean acidification' are as yet unclear; however, acid-base disturbances are apparent and may have consequences at the biochemical level. Alterations in $\mathrm{Na}^{+} / \mathrm{K}^{+}$-ATPAse enzymatic activity due to disturbances in extracellular fluid (and thus, intracellular) may lead to repercussions at the physiological level. The inability to maintain acid-base regulation and/or ionic/osmotic regulation (which is the mechanism of euryhalinity) may affect the survival of organisms in all aquatic environments (including freshwater, brackish and seawater) and may have profound effects on the salinity tolerance of euryhaline decapod crustaceans. In conclusion, it is demonstrated that as a result of hypercapnia and, subsequently, decreased environmental $\mathrm{pH}$, ionic regulation in 2 osmo/ionic regulator species is affected at a cost to the individual of significant acid-base alterations in internal $\mathrm{pH}$ homeostasis.

Acknowledgements. This study was funded by a British Ecological Society (BES) SEP grant awarded to A.D. We thank the 3 anonymous referees whose comments have much improved the manuscript.

\section{LITERATURE CITED}

Augusto A, Pinheiro AS, Greene LJ, Laure HJ, McNamara JC (2009) Evolutionary transition to freshwater by ancestral marine palaemonids: evidence from osmoregulation in a tide pool shrimp. Aquat Biol 7:113-122

Berglund A (1982) Co-existence, size overlap and population regulation in tidal vs. non-tidal Palaemon prawns. Oecologia 54:1-7

Blackford JC, Gilbert FJ (2007) pH variability and $\mathrm{CO}_{2}$ induced acidification in the North Sea. J Mar Syst 64:229-241

Burnett L, Terwilliger N, Carroll A, Jorgensen D, Scholnick D (2002) Respiratory and acid-base physiology of the purple sea urchin, Strongylocentrotus purpuratus, during air exposure: presence and function of a facultative lung. Biol Bull 203:42-50

Caldeira K, Wickett ME (2003) Anthropogenic carbon and ocean $\mathrm{pH}$. Nature 425:365

Cameron JN (1985) Compensation of hypercapnic acidosis in the aquatic blue crab, Callinectes sapidus: the predominance of external seawater over carapace carbonate as the proton sink. J Exp Biol 114:197-206

Cameron JN, Iwama GK (1987) Compensation of progressive hypercapnia in channel catfish and blue crabs. J Exp Biol 133:183-197

Cameron JN, Mangum CP (1983) Environmental adaptations of the respiratory system: ventilation, circulation and oxygen transport. In: Vernberg J, Vernberg WB (eds) The biology of Crustacea: environmental adaptations, Vol 8. Academic Press, New York, NY, p 43-63

Campbell PJ, Jones MB (1989) Osmoregulation of the estuarine prawn Palaemon longirostris (Caridea: Palaemonidae). J Mar Biol Assoc UK 69:261-272

> Charmantier G, Anger K (1999) Ontogeny of osmoregulation in the palaemonid shrimp Palaemonetes argentinus (Crustacea: Decapoda). Mar Ecol Prog Ser 181:125-129

> Dissanayake A, Galloway TS, Jones MB (2008) Nutritional status of Carcinus maenas (Crustacea: Decapoda) influences susceptibility to contaminant exposure. Aquat Toxicol 89:40-46

Feely RA, Sabine CL, Lee K, Berelson W, Kleypas J, Fabry VJ, Millero FJ (2004) Impact of anthropogenic $\mathrm{CO}_{2}$ on the $\mathrm{CaCO}_{3}$ system in the oceans. Science 305:362-366

Freire CA, Cavassin F, Rodrigues EN, Torres AH, McNamara JC (2003) Adaptive patterns of osmotic and ionic regulation, and the invasion of fresh water by the palaemonid shrimps. Comp Biochem Physiol A 136:771-778

Freire CA, Onken H, McNamara JC (2007) A structurefunction analysis of ion transport in crustacean gills and excretory organs. Comp Biochem Physiol A 151:272-304

Freire CA, Onken H, McNamara JC (2008) A structure-function analysis of ion transport in crustacean gills and excretory organs. Comp Biochem Physiol A 151:272-304

González-Ortegón E, Pascual E, Cuesta JA, Drake P (2006) Field distribution and osmoregulatory capacity of shrimps in a temperate European estuary (SW Spain). Estuar Coast Shelf Sci 67:293-302

> Gutowska MA, Melzner F, Langenbuch M, Bock C, Claireaux G, Pörtner HO (2010) Acid-base regulatory ability of the cephalopod (Sepia officinalis) in response to environmental hypercapnia. J Comp Physiol B 180:323-335

Henry RP, Cameron JN (1983) The role of carbonic anhydrase in respiration, ion regulation and acid-base balance in the aquatic crab Callinectes sapidus and the terrestrial crab Gecarcinus lateralis. J Exp Biol 103:205-225

Henry RP, Wheatly MG (1992) Interaction of respiration, ion regulation, and acid-base balance in the everyday life of aquatic crustaceans. Am Zool 32:407-416 
Henry RP, Kormanik GA, Smatresk NJ, Cameron JN (1981) The role of $\mathrm{CaCO}_{3}$ dissolution as a source of $\mathrm{HCO}_{3}{ }^{-}$for the buffering of hypercapnic acidosis in aquatic and terrestrial decapod crustaceans. J Exp Biol 94:269-274

Holthuis LB (1950) Shrimps and prawns of the world. An annotated catalogue of the species of interest to fisheries. FAO Fisheries Synopsis 125, Vol 1. FAO, Rome

IPCC (2001) Climate change 2001: the scientific basis. Contribution of Working Group I to the Third Assessment Report of the Intergovernmental Panel on Climate Change. Cambridge University Press, Cambridge

Ituarte R, López B, Mañanes A, Spivak E, Anger K (2008) Activity of $\mathrm{Na}^{+}, \mathrm{K}^{+}$-ATPase in a freshwater shrimp Palaemonetes argentinus (Caridea, Palaemonidae): ontogenetic and salinity-induced changes. Aquat Biol 3:283-290

Janas U, Spicer JI (2008) Does the effect of low temperature on osmoregulation by the prawn Palaemon elegans Rathke, 1837 explain winter migration offshore? Mar Biol 153:937-943

Kinne O (1971) Salinity: animals-invertebrates. In: Kinne O (ed) Marine ecology, Vol 1, Environmental factors, Part 2. Wiley Interscience, London, p 821-1083

Kurihara H, Matsui M, Furukawa H, Hayashi M, Ishimatsu A (2008) Long-term effects of predicted future seawater $\mathrm{CO}_{2}$ conditions on the survival and growth of the marine shrimp Palaemon pacificus. J Exp Mar Biol Ecol 367:41-46

Lignot JH, Spanings-Pierrot C, Charmantier G (2000) Osmoregulatory capacity as a tool in monitoring the physiological condition and the effect of stress in crustaceans. Aquaculture 191:209-245

Mantel LH, Farmer LL (1983) Osmotic and ionic regulation. In: Mantel LH (ed) The biology of Crustacea internal anatomy and physiological regulation, Vol 5. Academic Press, New York, NY, p 53-161

> Masui DC, Mantelatto FLM, McNamara JC, Furriel RPM, Leone FA (2009) $\mathrm{Na}+, \mathrm{K}+$-ATPase activity in gill microsomes from the blue crab, Callinectes danae, acclimated to low salinity: novel perspectives on ammonia excretion. Comp Biochem Physiol A 153:141-148

McGaw IJ, Reiber CL (2000) Integrated physiological responses to feeding in the blue crab Callinectes sapidus. J Exp Biol 203:359-368

McMahon BR, Burnett LE, Fur PL (1984) Carbon dioxide excretion and carbonic anhydrase function in the red rock crab Cancer productus. J Comp Physiol B 154:371-383

- Mendonça NN, Masui DC, McNamara JC, Leone FA, Furriel RPM (2007) Long-term exposure of the freshwater shrimp Macrobrachium olfersii to elevated salinity: effects on gill (Na+, K+)-ATPase [alpha]-subunit expression and $\mathrm{K}+-$ phosphatase activity. Comp Biochem Physiol A 146:534-543

Merchant M (2009) Miniaturization of a chloride ion assay for use in a microtiter format. Microchem J 92:80-82

Miles H, Widdicombe S, Spicer JI, Hall-Spencer J (2007) Effects of anthropogenic seawater acidification on acidbase balance in the sea urchin Psammechinus miliaris. Mar Pollut Bull 54:89-96

Morris S, Taylor AC (1983) Diurnal and seasonal variation in physico-chemical conditions within intertidal rock pools. Estuar Coast Shelf Sci 17:339-355

Pane EF, Barry JP (2007) Extracellular acid-base regulation during short-term hypercapnia is effective in a shallowwater crab, but ineffective in a deep-sea crab. Mar Ecol Prog Ser 334:1-9

Panikkar NK (1941) Osmoregulation in some palaemonid prawns. J Mar Biol Assoc UK 25:317-359

Parry G (1954) Ionic regulation in the palaemonid prawn Palaemon (=Leander) serratus. J Exp Biol 31:601-613

Pearson PN, Palmer MR (2000) Atmospheric carbon dioxide

Editorial responsibility: Angus Atkinson,

Cambridge, UK concentrations over the past 60 million years. Nature 406 : 695-699

Pierrot D, Lewis E, Wallace DWR (2006) CO2SYS DOS program developed for $\mathrm{CO}_{2}$ system calculations, ORNL/ CDIAC-105. Carbon Dioxide Information Analysis Center, Oak Ridge National Laboratory, US Department of Energy, Oak Ridge, TN

Pörtner HO, Reipschlager A, Heisler N (1998) Acid-base regulation, metabolism and energetics in Sipunculus nudus as a function of ambient carbon dioxide level. J Exp Biol 201:43-55

Rahn H, Baumgardner FW (1972) Temperature and acidbase regulation in fish. Respir Physiol 14:171-182

Ramirez de Isla Hernandez S, Taylor AC (1985) The effect of temperature on osmotic and ionic regulation in the prawn, Palaemon elegans (Rathke). Ophelia 24:1-15

Rankin CJ, Davenport J (1981) Animal osmoregulation. Blackie, Glasgow

Raven J, Caldeira K, Elderfield H, Hoegh-Guldberg $\mathrm{O}$ and others (2005) Ocean acidification due to increasing atmospheric carbon dioxide. Clyvedon Press, Cardiff

$>$ Robertson JD (1949) Ionic regulation in some marine invertebrates. J Exp Biol 26:182-200

> Seibel BA, Walsh PJ (2003) Biological impacts of deep-sea carbon dioxide injection inferred from indices of physiological performance. J Exp Biol 206:641-650

Siegenthaler U, Sarmiento JL (1993) Atmospheric carbon dioxide and the ocean. Nature 365:119-125

Smaldon G (1979) Bristish coastal shrimps and prawns, Vol 15. Academic Press, London

Spicer JI (1995) Oxygen and acid-base status of the sea urchin Psammechinus miliaris during environmental hypoxia. Mar Biol 124:71-76

Spicer J, Raffo A, Widdicombe S (2007) Influence of $\mathrm{CO}_{2}$ related seawater acidification on extracellular acid-base balance in the velvet swimming crab Necora puber. Mar Biol 151:1117-1125

Taylor AC, Spicer JI (1987) Metabolic responses of the prawns Palaemon elegans and P. serratus. Mar Biol 95:521-530

Taylor AC, Spicer JI (1991) Acid-base disturbances in the haemolymph of the prawns, Palaemon elegans (Rathke) and $P$. serratus (Pennant) (Crustacea: Decapoda) during exposure to hypoxia. Comp Biochem Physiol A 98:445-452

Truchot JP (1975) Blood acid-base changes during experimental emersion and re-immersion of the intertidal crab Carcinus maenas (L.). Respir Physiol 23:351-360

Truchot JP, Duhamel-Jouve A (1980) Oxygen and carbon dioxide in the marine environment: diurnal and tidal changes in rockpools. Respir Physiol 39:241-254

Underwood AJ (2005) Experiments in ecology: their logical design and interpretation using analysis of variance. Cambridge University Press, Cambridge

Wheatly MG, Henry RP (1992) Extracellular and intracellular acid-base regulation in crustaceans. J Exp Zool 263: 127-142

> Whiteley N, Naylor J, Taylor E (1995) Extracellular and intracellular acid-base status in the freshwater crayfish, Austropotamobius pallipes between 1 and $12^{\circ} \mathrm{C}$. J Exp Biol 198:567-576

Whiteley NM, Scott JL, Breeze SJ, McCann L (2001) Effects of water salinity on acid-base balance in decapod crustaceans. J Exp Biol 204:1003-1011

- Widdicombe S, Spicer JI (2008) Predicting the impact of ocean acidification on benthic biodiversity: What can animal physiology tell us? J Exp Mar Biol Ecol 366:187-197

Zeebe RE Wolf-Gladrow (2001) $\mathrm{CO}_{2}$ in seawater: equilibrium, kinetics, isotopes, Vol 65. Elsevier Oceanography Series, Elsevier, Amsterdam 